UDK 785.74:787.1/.4(497.12)»1945/...

\title{
NOVEJŠI SLOVENSKI GODALNI KVARTET
}

\author{
Andrej Rij a ve c (Ljubljana)
}

Godalni kvartet 20. stoletja ni ostal nekje na robu, kot oblika, $\mathrm{s}$ katero ni več možno ničesar novega glasbeno izraziti, ampak je spremljal in ponekod celo bistveno dopolnjeval podobo glasbenih iskanj našega stoletja: tako je bilo pri Hindemithu, pri Schönbergu, pa pri Webernu, da ne govorimo o kvartetnemu klasiku Béli Bartóku! ${ }^{1}$ Pri nas je v njihovem času kar najsodobneje rešil vprašanje kvartetnega zvoka in forme Slavko Osterc s svojim II. godalnim kvartetom (1934). ${ }^{2}$ Moralo pa je preteči nekaj desetletij, preden so bile njegove kompozicijsko-tehnične in stilne rešitve presežene, in to na ravni, ki vzdrži mednarodne kriterije.

Najpopolnejši pregled novejšega snovanja na področju godalnega kvarteta nudi Katalog 1972 Edicij Društva slovenskih skladateljev, ${ }^{3}$ ki upošteva samo tiskane skladbe, kar je tudi eno izmed vodil tega sestavka. Ob tem bi se lahko pojavil ugovor, češ, čemu ravno godalni kvartet, saj ni tako tipičen za novejšo komorno produkcijo na Slovenskem. Res je in ni res. Res toliko, kolikor ga številčno prekaša množica kompozicij za najrazličnejše zasedbe, kompozicij, ki imajo že polno desetletje svojo reproduktivno pobudo $\mathrm{v}$ ansamblu "Slavko Osterc« in tudi v Ateljeju Društva slovenskih skladateljev. Ni res, kolikor tudi godalni kvartet odseva glasbena hotenja sodobnih slovenskih skladateljev in ker najnovejše kompozicije dokazujejo, ${ }^{4}$ da je komorni zvok štirih godal še kako aktualen. Vse skladbe $\mathrm{v}$ omenjenem katalogu niso upoštevane, časovno samo tiste, ki so

${ }^{1}$ Pütz W., Studien zum Streichquartettschaffen bei Hindemith, Bartók, Schönberg und Webern, Regensburg 1968, 188 sl.

2 Prim. Rijavec A., Prvi i drugi gudački kvartet Slavka Osterca, Arti musices I, Zagreb 1969, 177 sl.

${ }^{3}$ Ljubljana 1972, 106.

4 Nemalo vzpodbud ima v zadnjih letih pri tem odlični Zagrebški godalni kvartet, ki so mu mnoge skladbe ali posvečene, ali pa jih je krstil in jim $\mathrm{s}$ tem zagotovil zgledno interpretacijo. 
nastale od leta 1945 dalje, in obenem tiste, ki so kompozicijsko značilne ali pa so že dosegle poustvarjalno priznanje.

Iz leta 1945 je V. godalni kvartet Lucijana Marije škerjanca (Allegro molto vivace, Adagio cantabile, Presto, Adagio - Allegro impetuoso). ${ }^{5} \mathrm{~V}$ luči predvojnega in povojnega slovenskega ustvarjanja, ki je bilo in ki je odprto na vse strani, stoji zadnji skladateljev tiskani kvartet $\mathrm{v}$ znaku velikega spoštovanja do tradicije. Formalno mu ni kaj očitati, in tudi sicer ne, saj imamo opraviti z delom, ki ga odlično definira Mersmannova označba romantične sonate, ki »ni več drama, konflikt nasprotujočih si sil, razvoj velikih antitez, ampak krog, ki niha med dvema poloma in se vedno znova zapira in $\mathrm{v}$ katerem imajo vsa nasprotja samo relativen pomen « ${ }^{6}$ Tak je škerjanc tudi $\mathrm{v}$ prvem stavku, ki je za razliko od ostalih (večinoma trodelnih) - sonaten: dovolj kompaktna prva tema, ki se ob svojih variantnih nastopih $\mathrm{s}$ ponavljanjem in sekvenciranjem simetrično širi in krči $\mathrm{v}$ smislu motivičnega in tematičnega dela; stranska misel $\mathrm{v}$ obliki romantično zasanjanega dvogovora med prvo in drugo violino; nato izpeljava, v kateri je celo nova, dramatična misel lirično nežna; v komprimirani reprizi pa dobi tudi slednja brezvoljno nostalgični značaj. Vse to se opira na maniristične obrazce druge polovice 19. stoletja: zdaj v šestnajstinsko spremljevalnem gibanju, ki je včasih albertijevsko tradicionalno, včasih pa blizu rešitvam, ki so dosegle

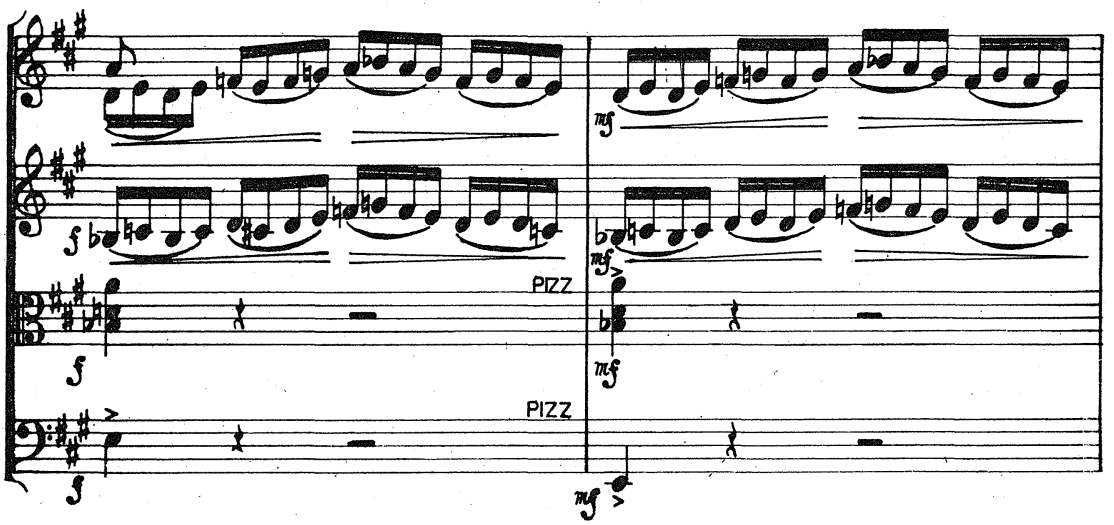

svojo sekstolno vtelešenje $\mathrm{v}$ Smetanovi Vltavi, zdaj v koncertantno solističnem stopnjevanju, ki zapelje v brahmsovski zamah (prim. str. 89).

Adagio cantabile je značilen primer zapoznele romantike, kjer neskončna melodija $\mathrm{z}$ vedno znova alteriranimi harmonijami stremi

5 Škerjanc L. M., III., IV. in V. kvartet. Partitura. Ljubljana, SAZU 1966, 93-182 (Razred za umetnosti. Serija za glasbeno umetnost 25).

${ }^{6}$ Mersman H., Die Kammermusik. Bd. 3, v: H. Kretzschmar, Führer durch den Konzertsaal, Leipzig 1933, 23. 


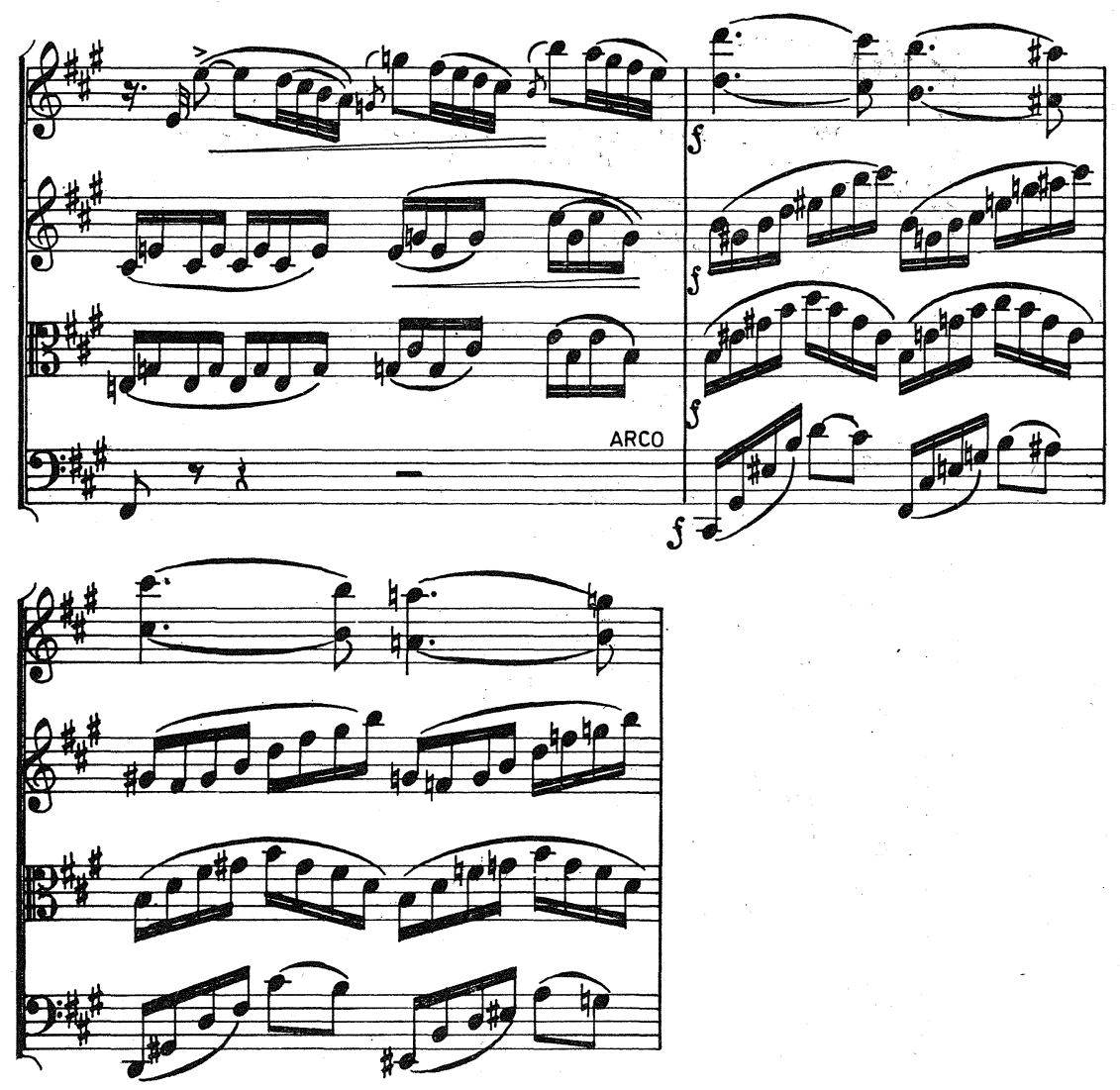

$\mathrm{k}$ novim razrešitvam, viškom in zadostitvam, a jih nikoli ne doseže, ${ }^{7}$ pri tem ne manjka niti mahlerjevskih vzdihov (prim. str.90).

Samo ponekod škerjanc zaustavi tok in s kromatično si sledečimi, vzporednimi harmonijami barvno preblisne kantabilni romantični tok, ki je bil že zdavnaj negovan tudi pri nas, a na ne dovolj profesionalni ravni. $\mathrm{Na}$ področju godalnega kvarteta dosega tukaj svoj višek in nasičenost.

Če v Prestu lahko najdemo vzore, ki segajo tja do Čajkovskega ${ }^{8}$ oziroma bližje, do Ravela, ${ }^{9}$ pa se v zadnjem stavku razkrije skladatelj v boljši luči. Tudi tukaj, kot v prejšnjem Prestu, zastavi stavek v fugatnem slogu, kar bi dalo misliti, da želi intenzivirati izraz. Toda ne. V tej novodobni gigui, ki je nekakšen lahkoten perpetuum mobile, je iskati enovitost $v$ suvereni maniri, ki je daleč od vsakega »učenega oblikovanja zvočnega tkiva.

${ }^{7}$ Szabolcsi B., Bausteine zu einer Geschichte der Melodie, Budapest 1959, 198.

8 škerjanc L. M., ib., 143/12 \& 144/sl.

9 Ib., $149 \& 150$. 

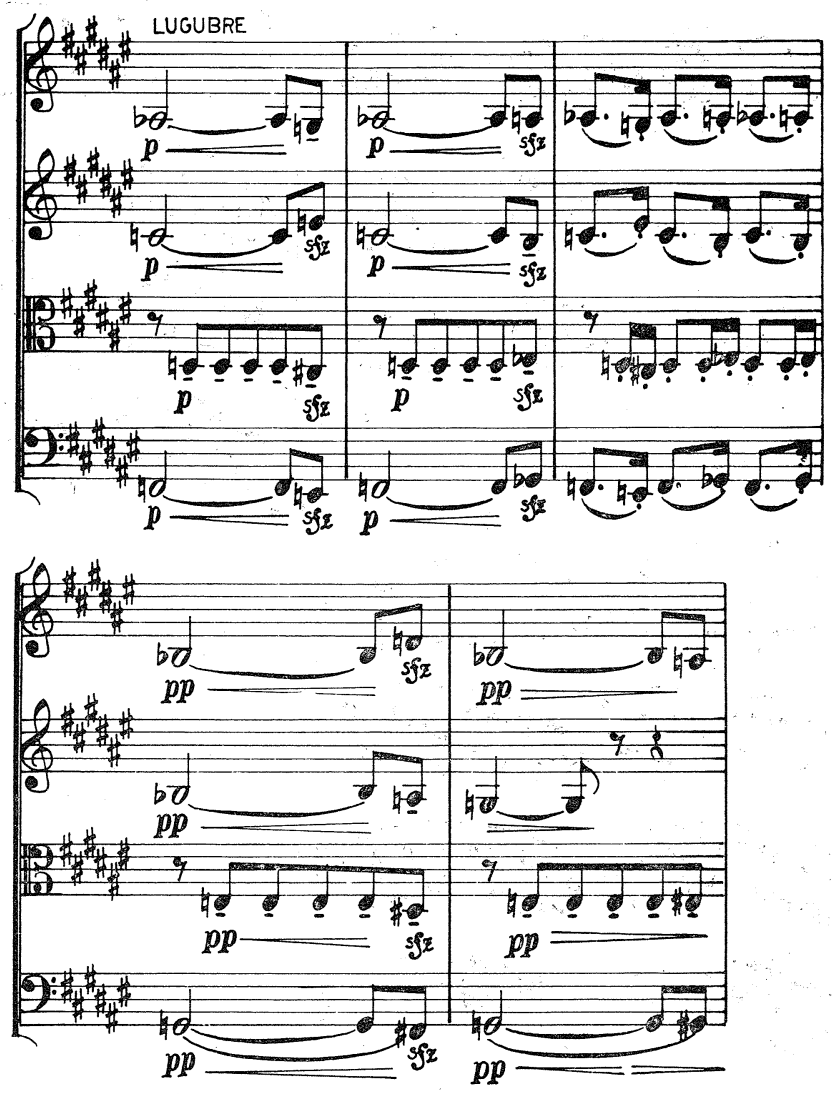

Poslej je nastala vrsta rokopisov, ki pa so največkrat obtičali po predalih njihovih ustvarjalcev. Tako od objavljenih kompozicij za kvartet v petdesetih letih samo Petrićev Godalni kvartet (1956) sveži ozračje. ${ }^{10}$ Pri tem je treba poudariti, da gre pravzaprav za šolsko delo, ki kaže, kaj vse so $\mathrm{v}$ tedanjem Klubu komponistov ljubljanske Akademije za glasbo poslušali, katera kompozicijska obzorja so si širili in v kateri smeri je takrat rastel njegov avtor.

Kompozicija je trostavčna (Sostenuto, Scherzando vivo, Lento), vendar je vsak izmed stavkov po dodatnih tempih in fakturi močno raznovrsten, tako da dobi celota lahkotnejši, suitni značaj, kar ustreza načinu izpričanega glasbenega mišljenja. Imamo opraviti $\mathrm{z}$ glasbeno govorico, ki je bila takrat že zdavnaj presežena, a pri nas ni bila pognala globljih korenin, prav gotovo v godalnem kvartetu ne. Vzore najde Petrić v partiturah Hindemitha in Bartóka, pri čemer si ne domišlja, da bi takrat mogel doseči mojstrstvo slednjega 446).

${ }^{10}$ Petrić I., Godalni kvartet, Ljubljana (samozaložba) 1956 (Ed. DSS 
$\mathrm{v}$ gradnji, zvoku in izraznosti. Vse to in podobno je $\mathrm{v}$ tem Petrićevem kvartetu veliko bolj preprosto in še najbolj podobno Bartókovim klavirskim priredbam folklornih tem, kar je razvidno iz menjajočega se metruma, melodičnih postopov in harmonij, ki niso več samo terčno grajene, ampak segajo že tudi $v$ kvartna in sekundna območja. Na primer začetek drugega stavka:
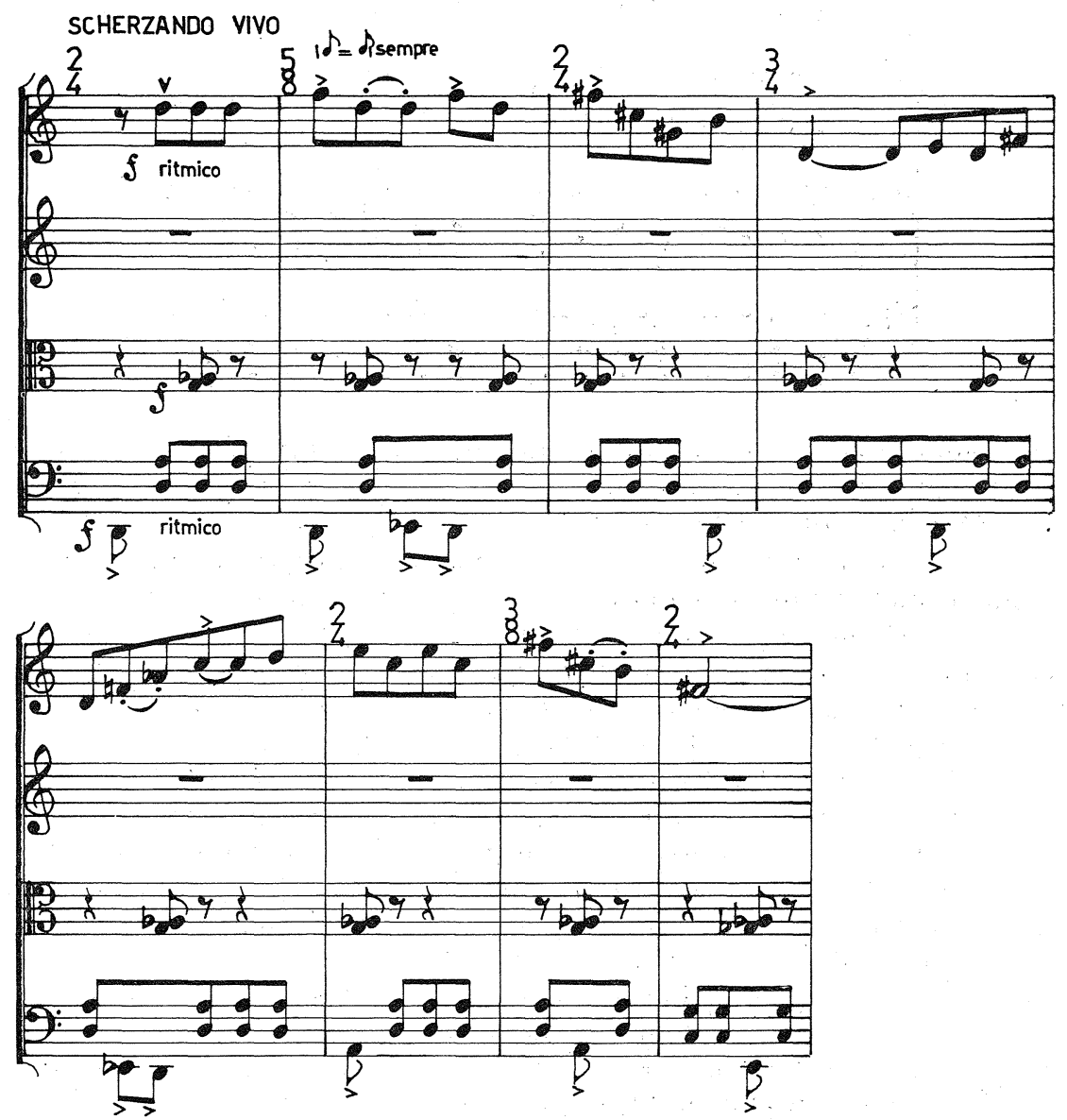

Ta folklorni element, pa čeprav gre za neslovensko folkloro, ki se mestoma ne brani niti južnoslovanskega "sevdaha«,11 je presenetljiv, ker dokazuje veliko večjo stopnjo prisotnosti folklore v slovenski glasbi, v tem primeru godalnem kvartetu, kot se ponavadi negativno posplošuje.

Da Petrićev primer ni osamljen, dokazuje leta 1959 nastali Godalni kvartet št. 3 (Moderato, Allegretto, Sostenuto, Animato) starej-

${ }^{11}$ Ib., 8 (Tranquillamente). 
šega, takrat in danes popolnoma drugače usmerjenega skladatelja Vilka Ukmarja. ${ }^{12}$ Allegretto ne more zatajiti folklornih vzorov, ki pa jih ni iskati na Slovenskem, ampak na južnoslovanskem jugu; tako

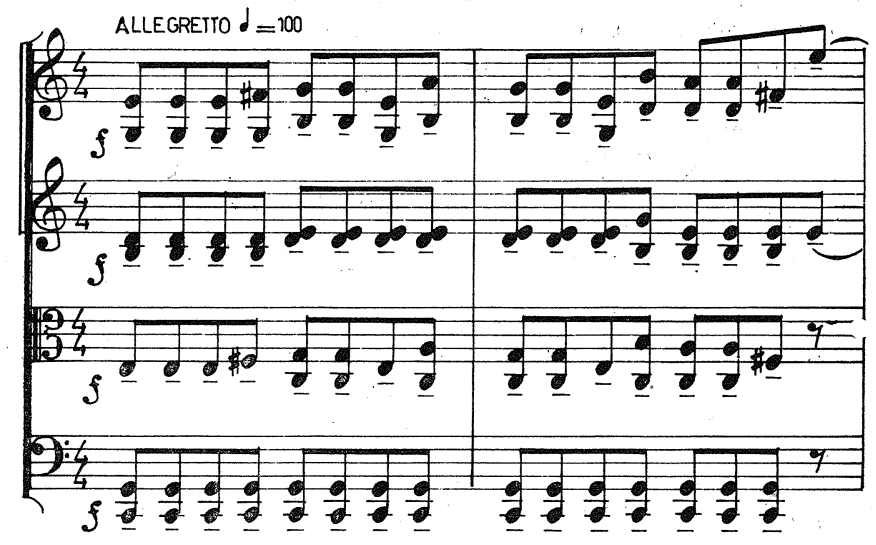

kar zadeva začetno misel kakor tudi njen nadaljnji razplet, ki sloni na poliritmično se množečem ostinatu $\mathrm{z}$ nekaterimi, značilno alteriranimi stopnjami (prim. str. 93).

Če je to in tako folklornost možno kompozicijsko dokazati na podlagi melodičnih postopov ter harmonskih in ritmičnih posebnosti, pa se nacionalne poteze izmikajo muzikološki analizi, ko le-ta ne more več operirati $\mathrm{z}$ oprijemljivimi kompozicijsko-tehničnimi pojmi. In vendar vstopna misel prvega stavka kar izziva spomin na "slovenskost «, ki se vsaj v godalnem zvoku vleče tja do Ljubljanskih akvarelov Emila Adamiča in še nazaj (prim. str. 94 zgoraj). ${ }^{13}$

Pri Ukmarju je živo tudi zanimanje za sodobno oživljanje evropske glasbene preteklosti. Osrednji Meno mosso istega stavka, ki sloni na ostinatu basa in kontrapunktsko vodeni I. violini, ki meditira $\mathrm{v}$ okviru ozkega ambitusa, medtem ko II. violina in viola samo maniristično dopolnjujeta glasbeni tok, odseva miselno zvezo z začetki skupinskega godalnega muziciranja $\mathrm{v}$ času znamenite Gabrielijeve Sonate con tre violini e basso, se pravi v času, ko še ni bil popolnoma izoblikovan nekaj stoletij trajajoči dur-molovski sistem. Tudi Ukmarjev kvartet je kljub nekaterim terčno razložljivim harmonijam (že) izven tega, saj se giblje $\mathrm{v}$ okvirih decentralizirane tonal-

${ }^{12}$ Ukmar V., Godalni kvartet št. 3, Ljubljana 1960 (Ed. DSS 93).

13 B. Loparnik se je $\mathrm{v}$ svojem članku »O nacionalnom $\mathrm{u}$ Lipovšekovim horskim kompozicijama" (Zvuk 108, 344 sl.) pred leti lotil zanimive in težavne naloge pobližjega opredeljevanja tipično slovenskih potez $\mathrm{v}$ kompozicijah Marijana Lipovška. Le-te je označeval s skladateljevo epsko zadržanostjo, negostobesednostjo, zunanjo treznostjo in notranjo liričnostjo itd., $\mathrm{z}$ izrazi, ki bi jih $\mathrm{v}$ Ukmarjevem primeru morali nanóvo določiti, ker bi avtomatično prenašanje lahko sicer pripeljalo do zaključka, da je Ukmar v tem kvartetu in tudi sicer "neslovenski« skladatelj. 
1.
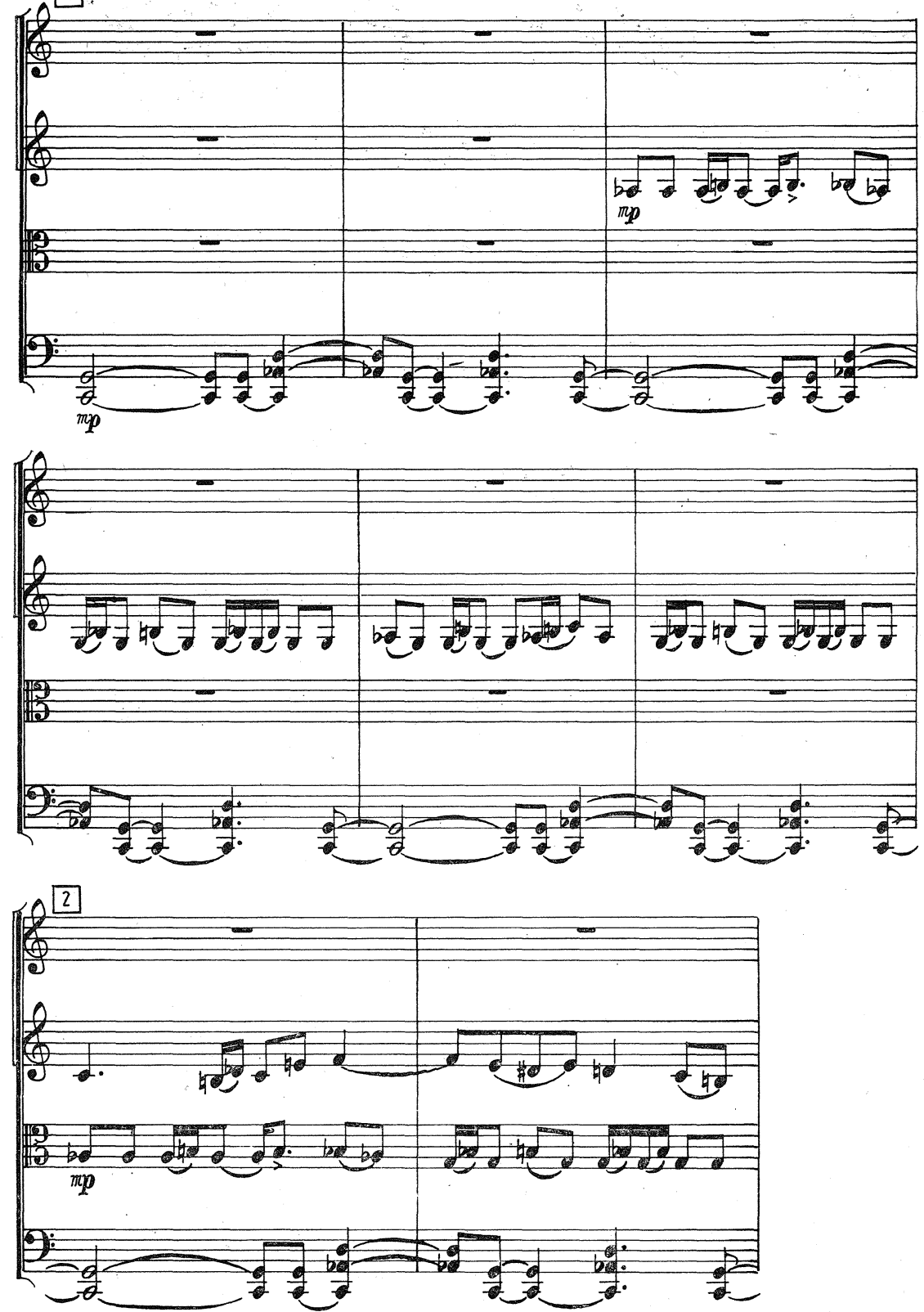

nosti. Kljub navidezni contradictio in adiecto ga njegovo zaostrovanje glasbene govorice vodi od romantične ekspresivnosti mimo nečesa, kar bi lahko imenovali romantični ekspresionizem, do ekspre- 

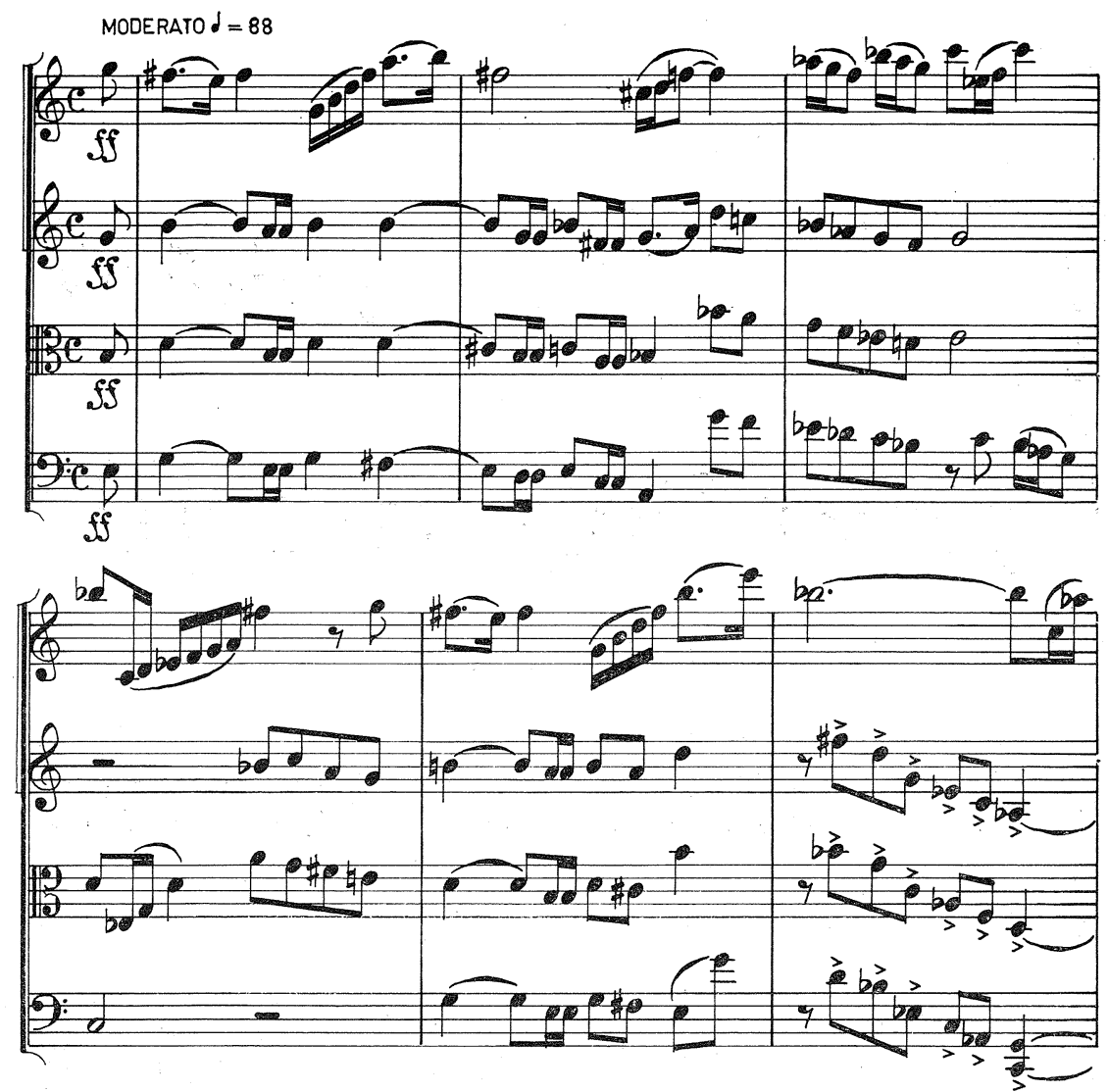

sionističnosti, ki je že brez romantičnih primesi in ki kaže naprej v bolj moderne zvočne rešitve:

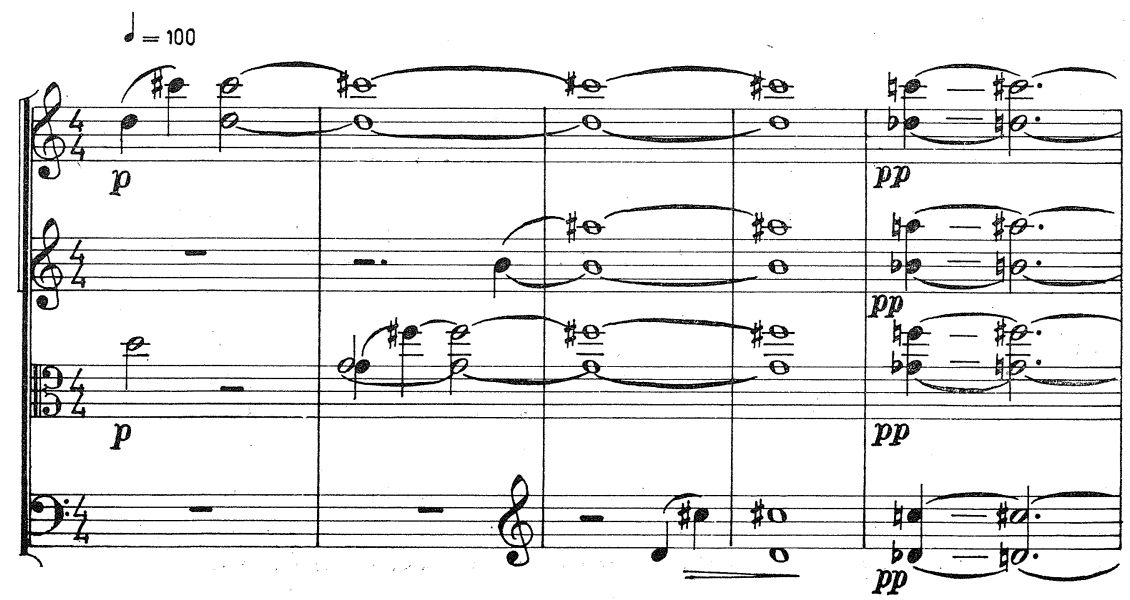


Ta konglomerat stilno raznoterega, slovenskega in neslovenskega, starega in novega, lahkotnega in resnega je nujno zahteval strogo formalno gradnjo, ki bi prenesla ta pêle-mêle raznovrstnih glasbenih domislic, ker, kot je lahko že jasno iz doslej povedanega, Ukmar v tem kvartetu ne izhaja iz ene oziroma iz maloštevilnih glasbenih misli, s katerimi bi potem $\mathrm{v}$ transformacijah pregnetal celoto, ampak daje duška svoji invenciji. Kljub temu oziroma ravno zato so med seboj kontrastni stavki oblikovno strogo uravnovešeni: če že niso trodelni, so simetrični v smislu »Brückenform«. Mimo tega so po tempu sorodni stavki prežeti $\mathbf{z}$ auto-citati: osrednji del Sostenuta na primer $\mathrm{z}$ drugače instrumentiranim Menom mossom ter bistvenimi mislimi drugega tematičnega kompleksa Moderata, ali, na primer, ob novem gradivu uporabi skladatelj $\mathrm{v}$ zaključenem Animatu cele pasuse iz osrednjega dela Allegretta in nato iz njegovih mejnih delov. $\mathrm{Na}$ ta način dosega zadostno integriranost členov, saj ob ponávljanju že znanega postane tudi novo organski del višje celote.

Če ne štejemo izdaje škerjančevih kvartetov (1966), je moralo miniti skoraj desetletje, da je doživelo svoj krst in bilo tudi izdano kvalitetnejše delo za godalni kvartet. Mislim na Dve skladbi za godalni kvartet Vladimirja Lovca, ki sta po naročilu Društva slovenskih skladateljev nastali leta $1968 .{ }^{14}$ Vsekakor gre za skladbi, ki sta obogatili slovensko kvartetno literaturo s svojo jasnostjo, oblikovno uravnovešenostjo in klenostjo glasbene govorice, čeprav je tudi tukaj opaziti stilna nihanja ter možnosti, kamor pa se skladatelj ni usmeril. V sedaj že nekoliko zastarelem drugem zvezku Muzičke enciklopedije beremo o Lovcu med drugim tudi naslednje: »Njegova djela, izgradjena na klasičnim uzorima, oslanjaju se stilski na elemente romantike i impresionizma.$^{15}$ Pojem impresionizma je pri teh kvartetnih kompozicijah brezpredmeten, ne pa ostali dve etiketi. Pri prvi skladbi gre za trikratno variantno ponovitev dramatičnega (Allegro risoluto) $\mathrm{v}$ izmenjavi $\mathrm{z}$ Lentom affetuosom, pri čemer so $\mathrm{v}$ obeh delih očitne intervalne sorodnosti, kar daje skladbi tematično enovitost. Kompozicija začne $\mathrm{v}$ unisono, $\mathrm{z}$ ne-tonalno, razgibano melodično linijo, ki bi lahko zapeljala v ekspresionistične vode, a jo Lovec kot kontrast sledeči, osrednji misli obdela s prehajalno-pretolmačevanimi dur-molovskimi harmonijami. Sledi dramatična tema, kı kar izžareva utripajočo ritmičnost (prim. notna primera na str. 96 in 97).

Ker je odtehtanosti forme $\mathrm{v}$ njeni rasti in ponovljivosti, v velikem in majhnem z lahkoto slediti, se more skladba kljub začetni tradicionalnejši vertikali uvrstiti med klasične primere (sicer zapoznelega) slovenskega neoklasicizma (prim. notni primer na str.98).

Druga skladba je pravzaprav zvočno nekoliko zaostrena izpovedna različica $\mathrm{v}$ začetnem Lentu affettuosu nakazanega večglasja, tega minulega, a intenzivnega, sočnega, nenehno prelivajočega in napredujočega zvoka, ki je ves - zdaj v tem, zdaj v onem glasu $470)$.

${ }^{1 / 4}$ Lovec V., Dve skladbi za godalni kvartet, Ljubljana 1972 (Ed. DSS

${ }_{15}$ Zagreb 1963, 124. 

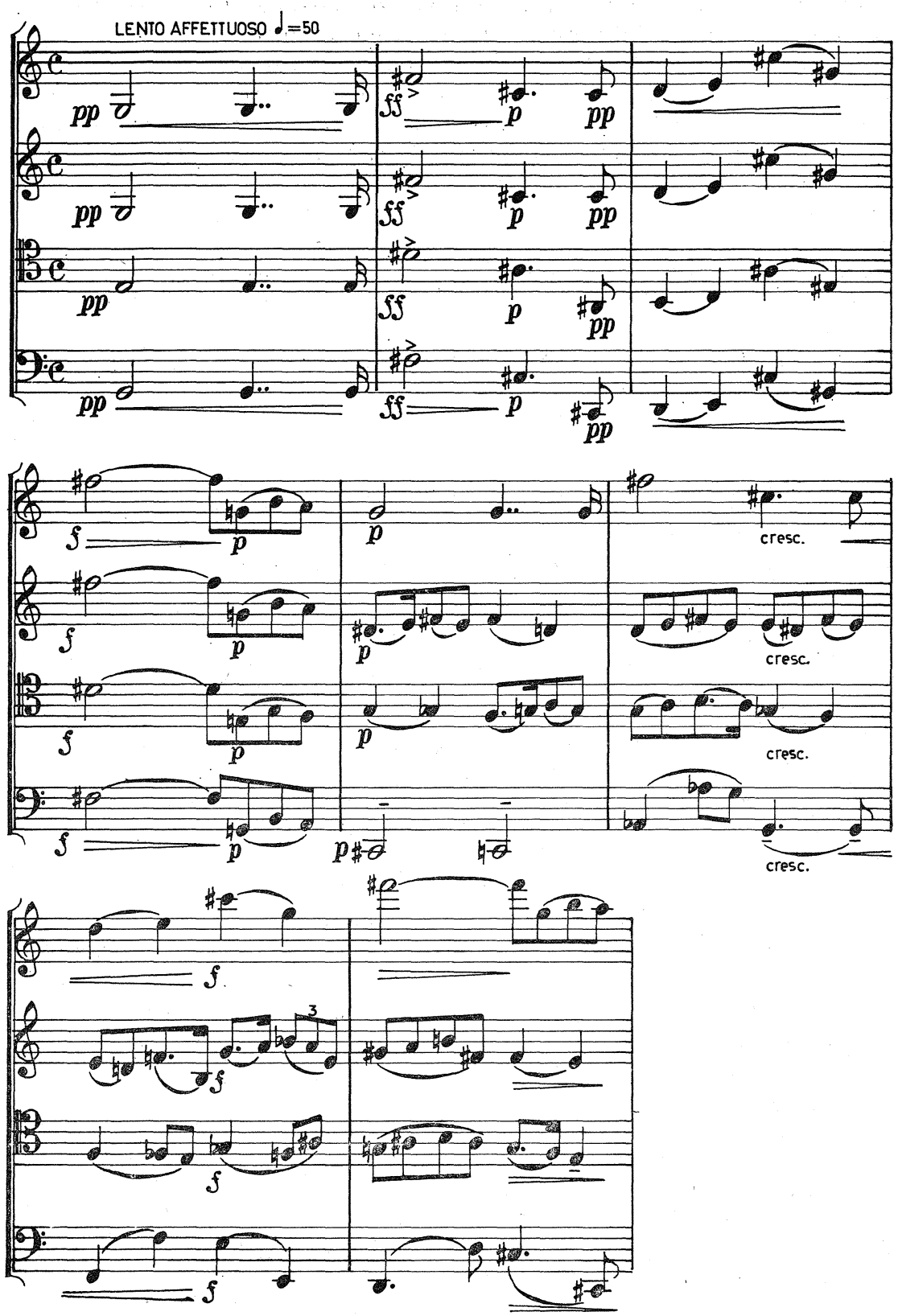

pregneten $s$ tematičnim. Kar je bilo prej samo prehodnega pomena, je sedaj razširjeno na vso skladbo, s čimer se smiselno uravnovesi ta posrečeni diptihon. 

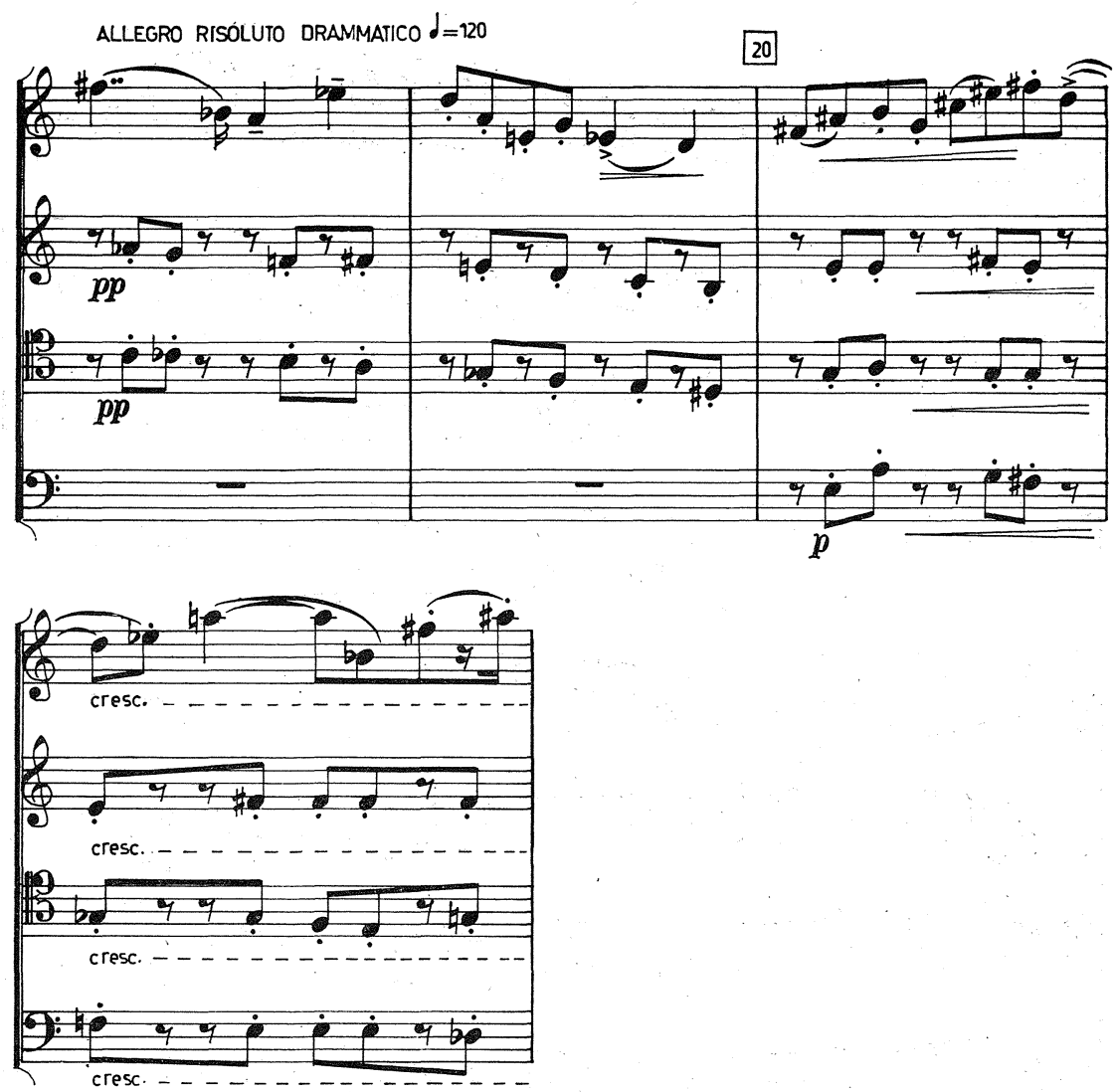

Že sedaj se vsiluje misel, da je ena izmed značilnih potez slovenskega kvartetnega skladanja lirična nota, saj se - mutatis mutandis - prikrade tudi v Quatuor 1969 (Avant... Après ...) Iva Petrića. ${ }^{16} \mathrm{Na}$ primer začetek drugega stavka (primer na str. 99).

$\mathrm{Na}$ začetku, v opombi, ki daje pregled nad znaki (notnimi vrednostmi in pavzami), je brati med drugim tudi to-le: "Les mesures ne sont organisées que pour l'orientation«. Se pravi, da imajo znaki samo orientacijsko vrednost, kar močno stopnjuje soigro, saj te in take proporcionalne notacije zahtevajo večjo samokontrolo. ${ }^{17}$ Zato mora vsak izmed izvajalcev imeti celotno partituro, ker bi izpisovanje posameznih partov bilo pač neuporabno in nesmiselno. Relativnost takega notiranja se kaže že $\mathrm{v}$ horizontali, še bolj pa v vertikali, ko jo skladatelj - v želji, da ne pride do nehotenega prekrivanja ključnih mest - ponekod korigira (s črtkanimi navpičnimi pu-

16 Petrić I., Quatuor 1969 à la memoire de mon père, Ljubljana 1972 (Ed. DSS 477).

1" Boehmer K., Zur Theorie der offenen Form der Neuen Musik, Darmstadt $1967,141-142$. 

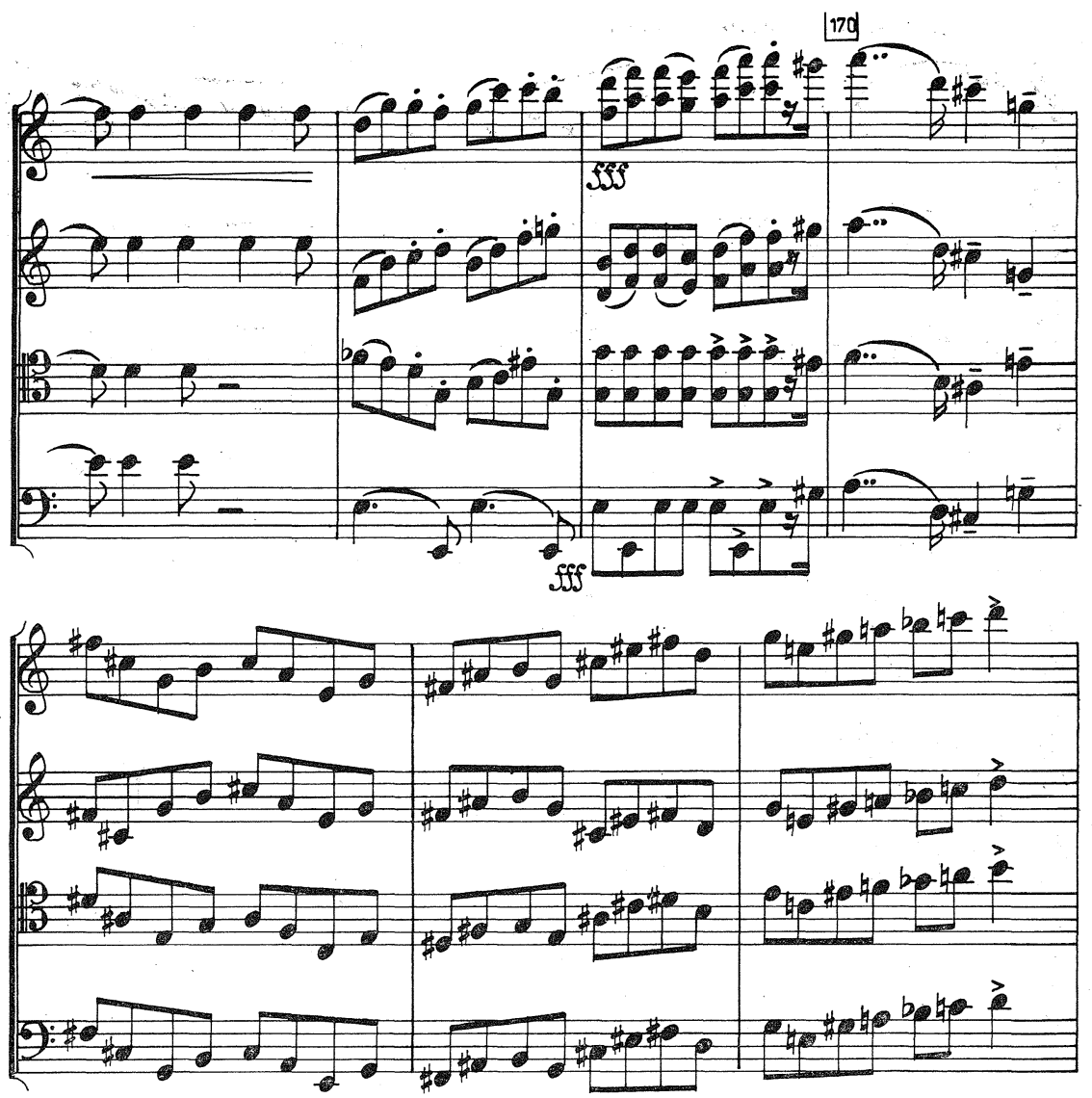

ščicami, $\mathrm{z}$ opombami "col 1. vno.« in podobno), ponekod pa aleatorično sprosti. To sta skrajnosti, pri čemer imajo tudi skupni pavzni predahi vlogo sukcesivnih navpičnih korektivov. Naj bo tako ali drugače, gre za notacijo, ki jasno odseva hotenja skladatelja, notacijo, ki stopnjuje soigro, ne da bi zmanjševala stopnjo avtorstva ustvarjalca. $S$ tem seveda odpadeta vsakršna skrb in dvom s strani izvajalcev. ${ }^{18}$

Petrić s pridom izrablja dotlej znane načine vzbujanja zvoka, ne da bi se posluževal izvengodalnih efektov: udarcev po trupu godal, po stojalih, arco igranja po hrbtu instrumentov in podobno. Ne, gre za pravi godalni kvartet, zaradi česar je bila naloga še težja: napisati skladbo, v kateri zvok sam ni cilj in obenem vsebina kompozicije. Da je temu res tako, je mogoče potrditi tudi s presenetljivo številno uporabo izrazov, s katerimi se želi dodatno opredeliti poustvaritev: intenso, brutale, sonoro, nervoso, espressivo, murmurando,

18 Palm S., Zur Notation für Streichinstrumente, Darmstädter Beiträge zur Neuen Musik, Mainz IX/1965, 87 sl. 
energico, agitato, vivo, delicato in še in še; izrazov torej, ki že po tradiciji nosijo v sebi določeno čustveno kvaliteto, ki je tudi disentimentalizacija glasbe v 20. stoletju ni mogla razvrednotiti.
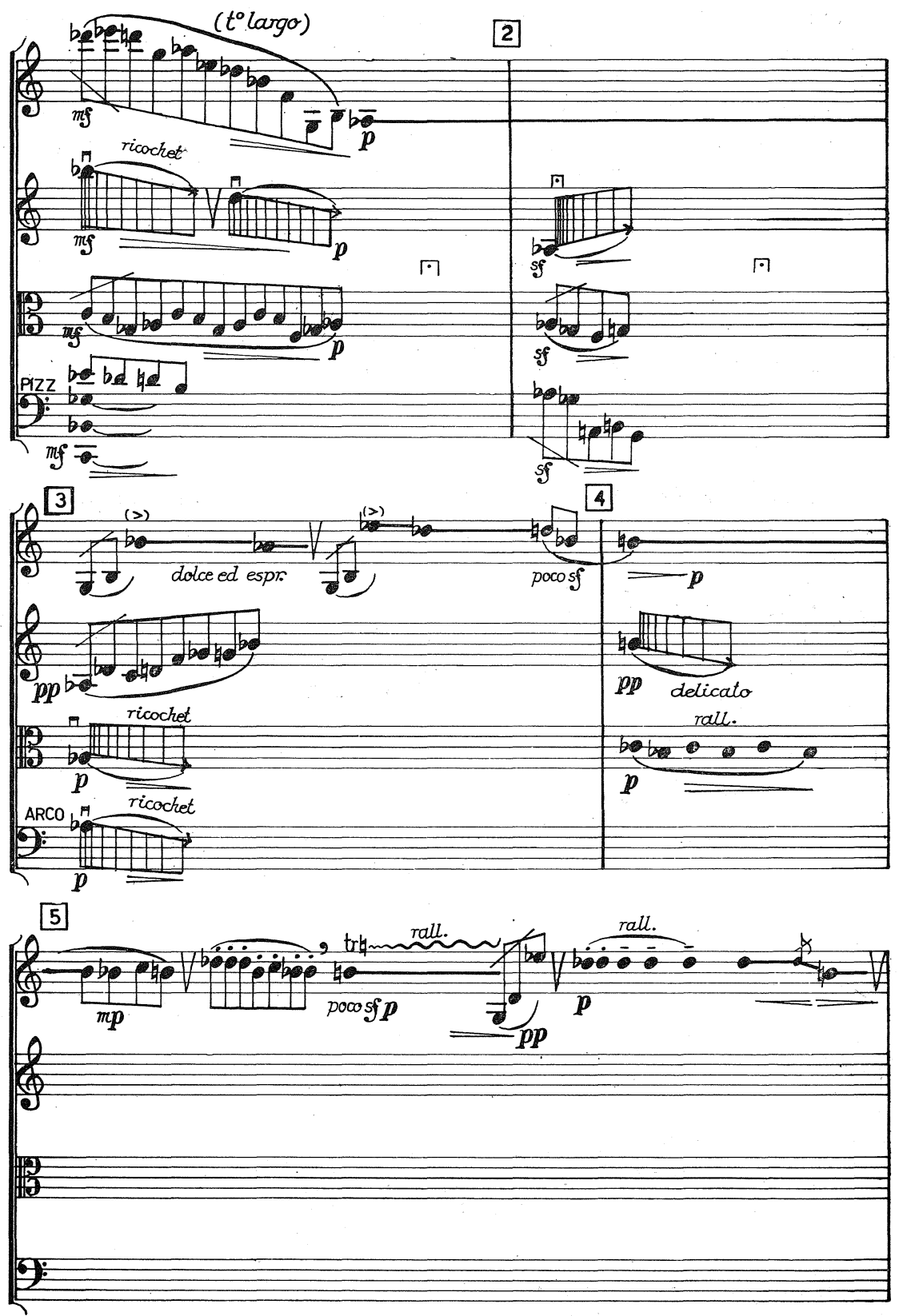
In še nekaj. Ta in naslednja kvarteta, o katerima bo še govor, kažejo na uspešnost postserialnega komponiranja. Le-to se je namreč rešilo diktatorskega, totalnega organiziranja forme, ki je segalo $\mathrm{v}$ najbolj oddaljena območja in zato ni učinkovalo nikjer, s svojim nenehnim variiranjem, ki ni upoštevalo časa, potrebnega, da se doumejo strukturne spremembe, je poslušalca informacijsko preobtežilo. ${ }^{19}$

Vsak od stavkov je tematično - mislim, da lahko govorimo o tematičnem, tudi ko ni teme $\mathrm{v}$ klasičnem smislu - enovito koncipiran, pa tudi oba stavka kažeta na nekatere medsebojne sorodnosti. Skladatelj se namreč nenehno poigrava $\mathrm{z}$ istim ali nekoliko transformiranim gradivom. Na eni strani so tu dolgi toni - longae, ki v zapovrstju, sozvočju ali "polifonskem« vstopanju največkrat vsebu-

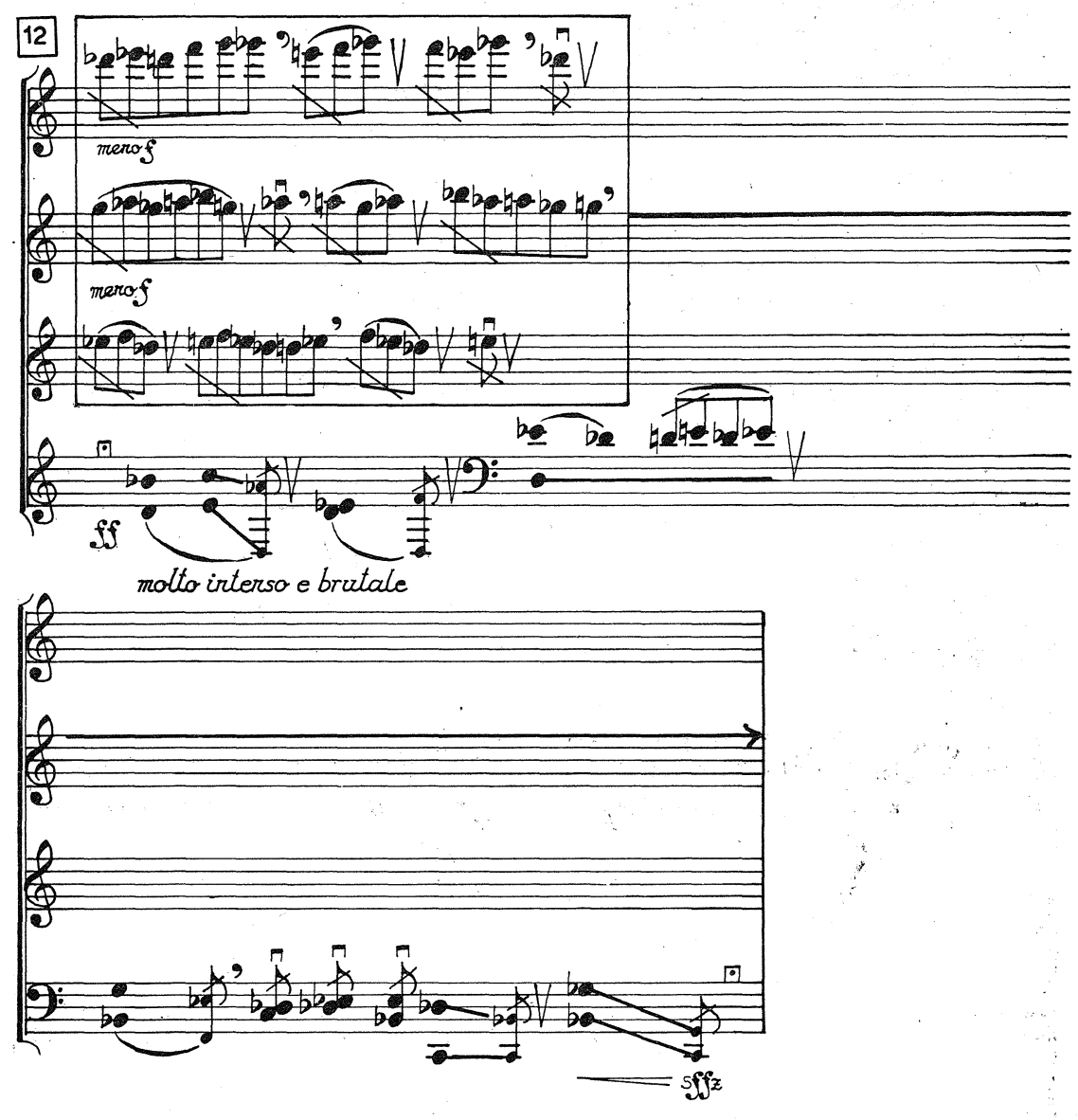

${ }^{19}$ Boehmer K., ib., 48-51. 
jejo interval sekunde (oziroma njene obrnitve in oktavne povečave), kar tipizira zvočno polje. Na drugi strani je prisotno drobno vrvrenje, ki ustvarja lebdeče zvočne ploskve. Te so zdaj v drugem planu, ob glavnem dogajanju, zdaj v prvem, in postanejo bistven nosilec zvočne izpovedi.

Zasnova prvega stavka je podana že v sfugatnem« začetku, medtem ko je iz notranje kontrastnega in diferenciranega stavka jasno spoznavna osnovna oblikovna zamisel, po kateri napetost po krepko zastavljenem izhodišču vpada, da bi v drugi polovici privedla do dramatičnega zaključka.
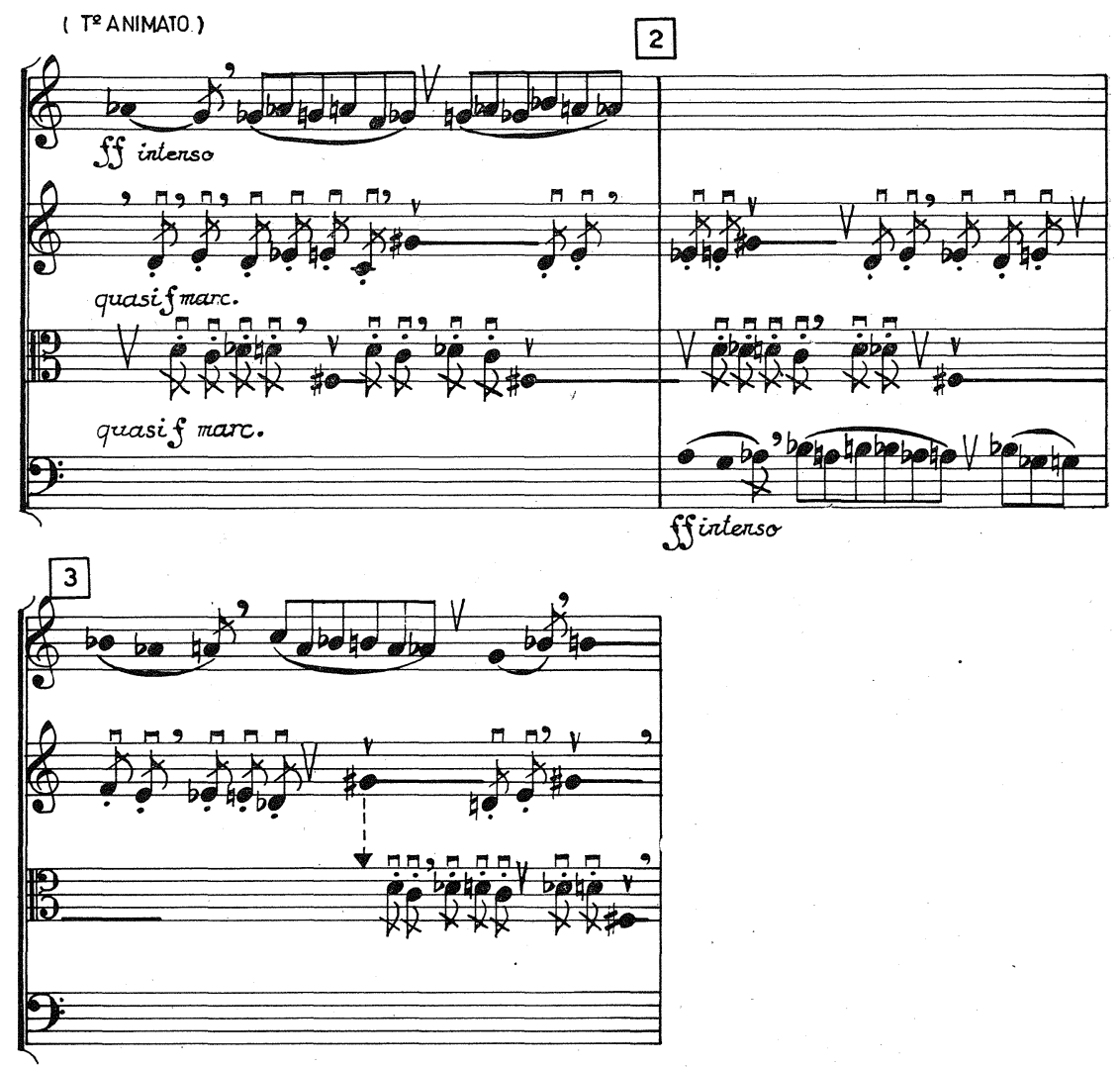

Après ... je pravo nasprotje prvega stavka, saj se začne $\mathrm{z}$ nekoliko elegično, lirično ekspresivnostjo, ki se sicer ekspresionistično še stopnjuje, a vrača v »delikatno", »flagioletno tožbo. Le tu in tam se pojavi kak zvočni izbruh, nato vedno znova in dokončno vrnitev $\mathrm{v}$ nič. Prejšnje krepkosti in zvočnega vrvrenja, ki spravlja zvok na področje med tonom in šumom, ni več. In vendar to tonsko drobljenje ni poniknilo, ampak se je samo razpotegnilo, obdržalo iste 
intervale, to je tematične značilnosti ter postalo povezujoče in zaokrožujoče zvočno tkivo:

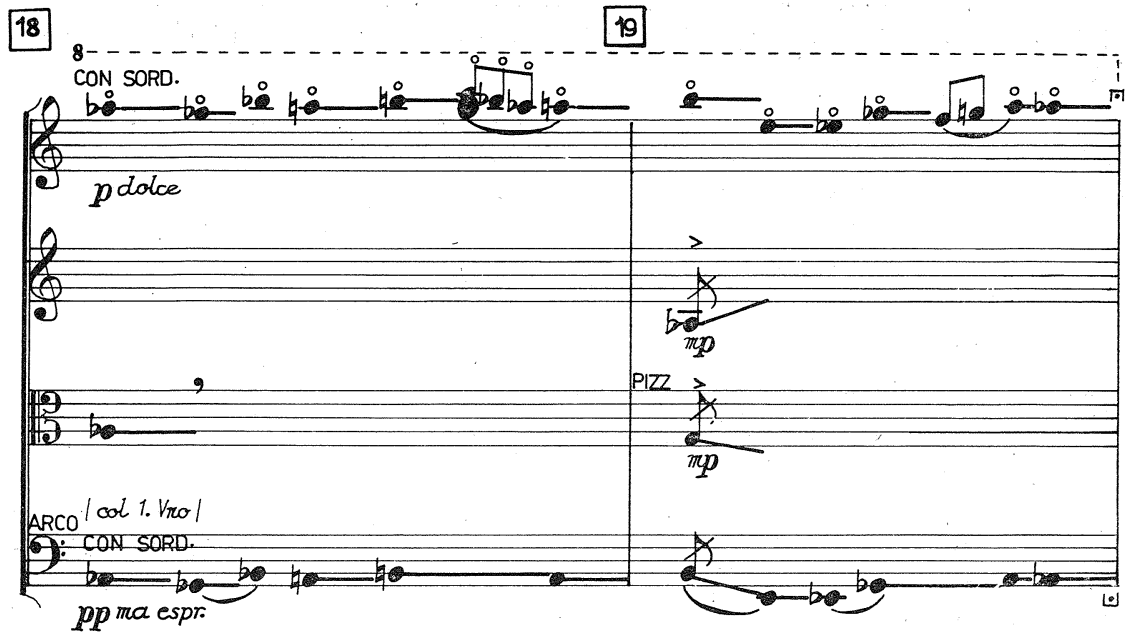

Če je Petrićev Quatuor sinteza dotedanjega razvoja godalnega zvoka, je Triptychon Primoža Ramovša iz istega leta že na konici novih zvočnih iskanj. ${ }^{20}$ Posamezni stavki imajo samo metronomske označbe za tempo; tu so tudi označbe za načine vzbujanja zvoka in za dinamiko, a ni nobenih italijanskih literarnih prislovov.

Začetek prvega stavka je s svojim fff na zgornjih mejah zvočnih možnosti, zato ga skladatelj uporabi samo kot začetni efekt. Pač pa $\mathrm{v}$ tem izrazito vertikalno zasnovanem stavku umno izrablja sekundna razmerja, ki so podana $\mathrm{v}$ teh uvodnih sozvočjih: bodi komprimirana $\mathrm{v}$ grozde, bodi vezana $\mathrm{s}$ kvartami $\mathrm{v}$ značilne zvočne ploskve, kot jih nakazuje že omenjeni primer (primer na str. 103).

Če je prvi stavek fiksiran, je drugi samo občasno tak, sicer pa aleatorično zasnovan z ligetijevskim vrvrenjem, ki se kaže kot končna posledica bartókovske »Klangmusik « ${ }^{21}$ in ki se v posameznih plasteh med seboj polifonsko izmenjuje in imitira, postaja trmasto nadležno, se nalaga, razredči, izživi in doživi lastno izginotje (gl. str. 104).

Tretji stavek predstavlja zaključni, pomirjajoči pendant prvemu stavku. In vendar je Ramovšev zivok v primerjavi s Petrićevim veliko bolj zaostren. $\mathrm{Na}$ sledi je nekakšnemu negodalnemu orgelskemu zvoku, ki je z elektronskimi sredstvi igraje dosegljiv. Spremembe v gostoti, barvi, dinamiki so postale bistvene in obenem izključne vsebinske komponente skladbe. ${ }^{22}$ Zvok je postal tu obenem sredstvo in cilj, samemu sebi samozadosten, vendar pa brez izventonskih impu-

20 Ramovš P., Triptychon za godalni kvartet, Ljubljana 1972 (Ed. DSS 324, HG 973).

32 sl.

21 Traimer R., Béla Bartóks Kompositionstechnik, Regensburg 1956,

22 Dibelius U., Moderne Musik 1945-1965, München 1966, 290. 

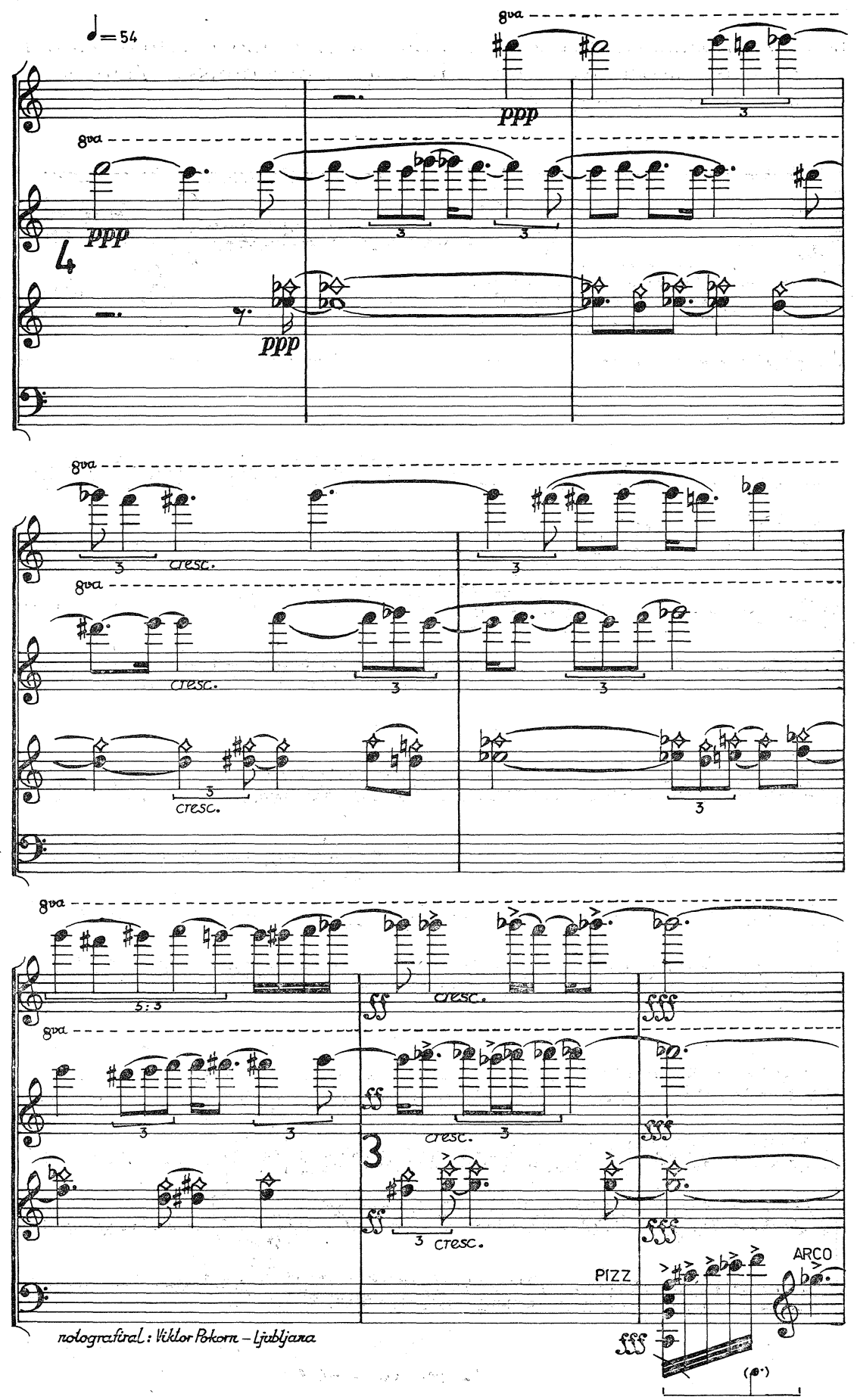
tacij. Za razliko od Petrićevega kvarteta je Ramovš veliko manj izvenglasbeno asociativen, torej izrazito neprogramski. Zato je pa drznejši in bolj avantgarden.
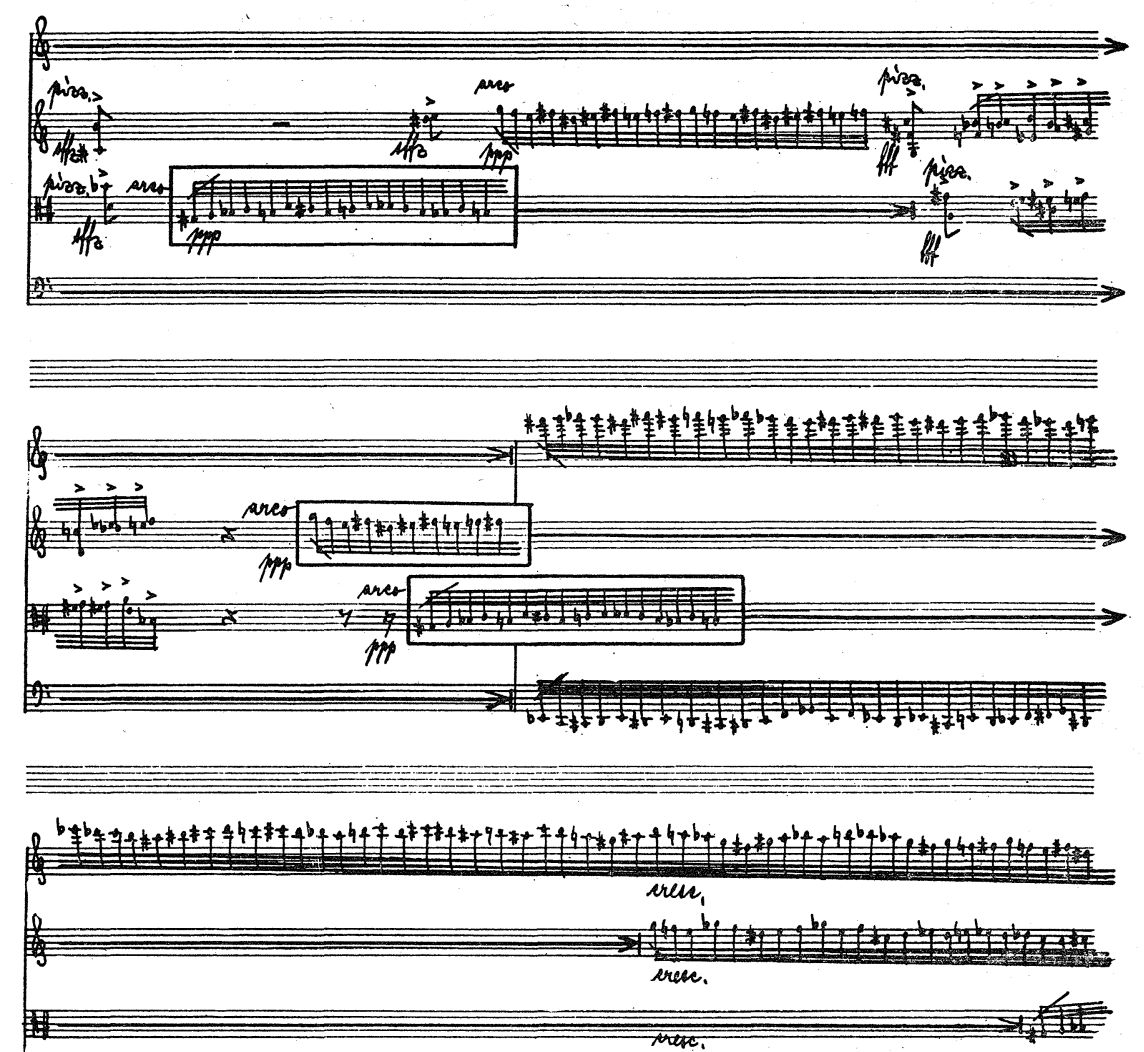

\begin{tabular}{lll}
2 & \\
\hline
\end{tabular} arese.

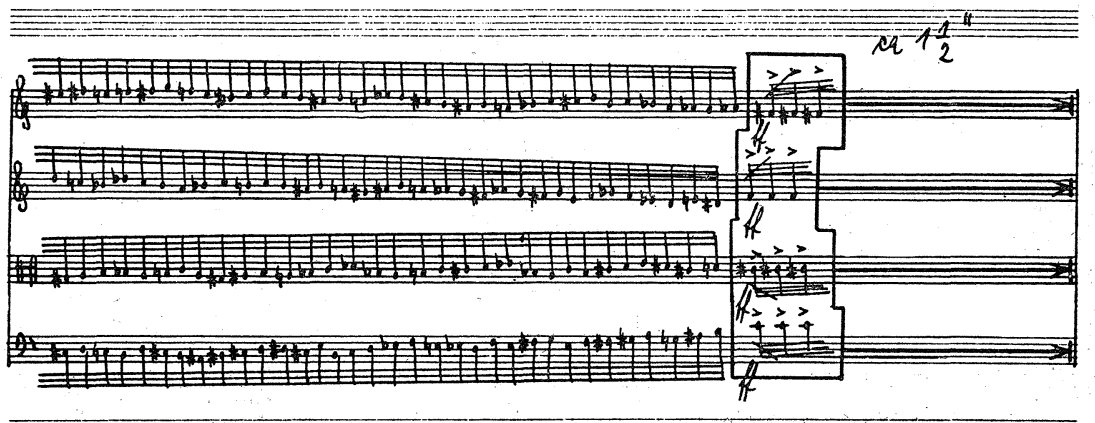

$$
\text { Ed. DSS } 479-H G 973
$$


In na koncu je še najnovejši slovenski kvartet, Darijana Božiča Pop-art III (1971). Kompozicija predstavlja nadaljevanje prejšnjih pop-artov, katerih posamezni stavki nosijo naslove neglasbenih form: tukaj, Forma V in Forma VI. Kljub pop-artovskem vpletanju raznorodnega - $\mathrm{v}$ prvem so to bili piccolo in trije predmeti, $\mathrm{v}$ drugem magnetofonski trak - se zdi slednji najčistejši, saj vključuje samo štiri godalce; izven njih ničesar - razen, kot dopolnilo uporablja ponekod $\mathrm{v}$ drugem stavku njihove fonetične zmožnosti. Kvartet je doživel uspešen, celo zelo uspešen krst na lanski jugoslovanski glasbeni tribuni v Opatiji. Morda zavoljo izvedbe? Res, ta je bila na višini. Da ni torej to bil le "Zagrebški godalni kvartet« in ne "Božič«, saj obstoje ansambli, na primer Globokarjev Free Music Group, ki so pri svobodnem improviziranju večkrat prepričljivejši kot pa pri izvajanju notno manj ali premalo determiniranih kompozicij, ki s svojo preveliko svobodo pomenijo paraliziranje odločanja komponista in njegovo praktično izključitev? ${ }^{23}$
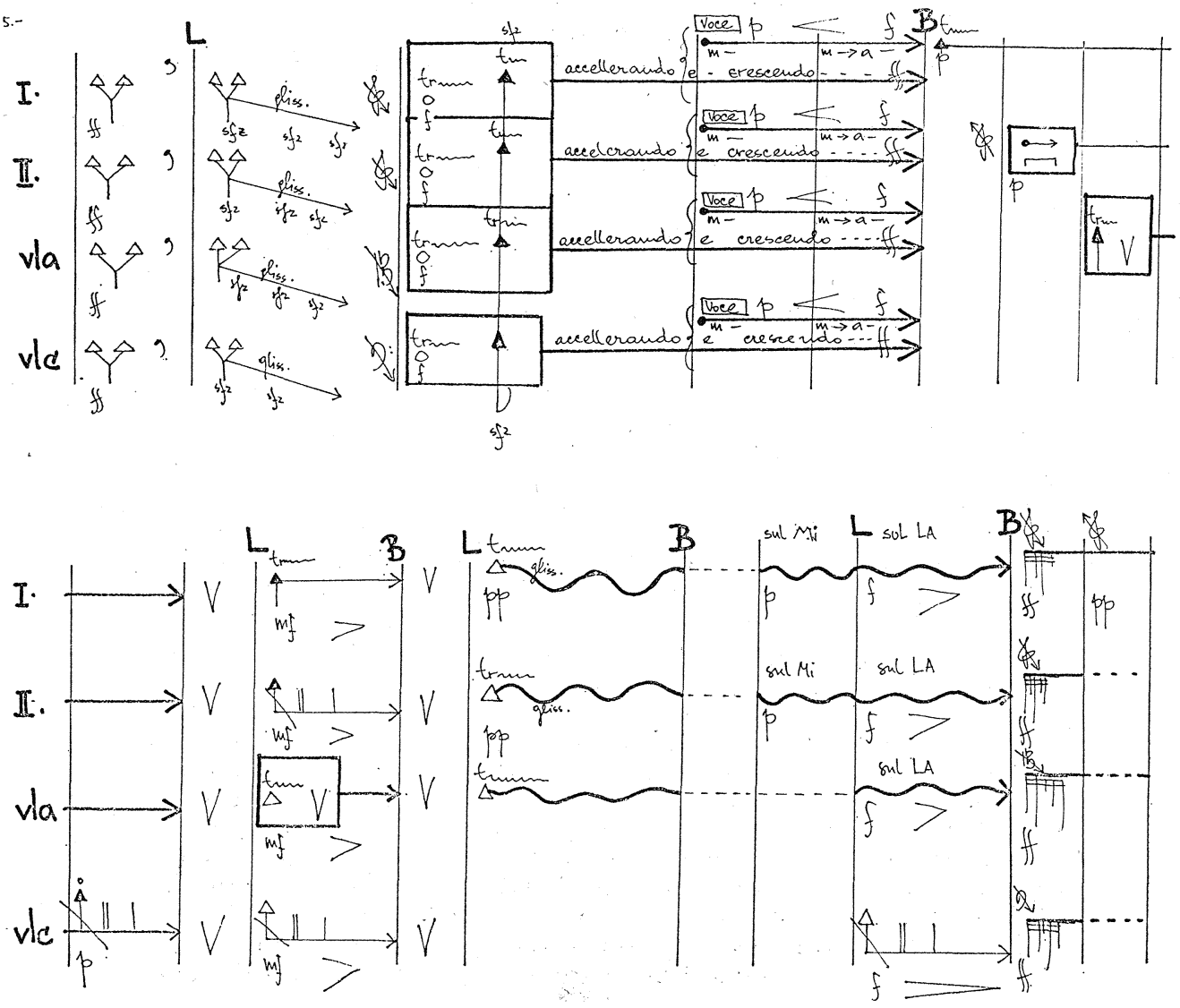

23 Boehmer K., ib., 157. 
Partitura to zanikuje. V njej je namreč malo samoustvarjalne svobode, čeprav je angažiranost ansambla močno stopnjevana, kar je tudi cilj tovrstnih iskanj $\mathrm{v}$ svetu. ${ }^{24}$ Le deloma lahko reproduktivec izbira, ker mora večinoma slediti skladateljevemu hotenju. Ključna mesta so $\mathrm{v}$ glavnem fiksirana, samo pota $\mathrm{k}$ njim so različna, a kompozicijsko tudi predvidena. Kvartet je iz dveh kontrastnih stavkov: prvega, statičnega, in drugega, dinamičnega, pri čemer je opaziti smiselno, to je estetsko sprejemljivo razporeditev različnih elementov oziroma parametrov, ki bi jih lahko zreducirali na parametre gibanja in mirovanja, in na parametre, ki glede na načine vzbujanja povzročajo barvne posledice. Če $\mathrm{k}$ temu dodamo še lego - visoko, srednjo in nizko, dinamiko ter časovno komponento, ki jo proporcionalno nakazujejo dolgi in kratki takti, je to vse. In obenem podobno stradicionalnemu" skladanju, ko si skladatelj zamisli svojo bodočo kompozicijo $\mathrm{v}$ njenih osnovnih konturah. In vendar drugače: ker sedaj ne izhaja iz teme, tipičnega motiva, izhodiščnega sozvočja in podobno, ampak zvočno platno polni s kombinacijami teh, na zvočne »prafaktorje» reduciranih gradbenih elementov. Rezultat je polifonsko sosledje zdaj bolj statičnih zdaj bolj mobilnih zvočnih barv $\mathrm{v}$ sicer značilno godalnem zvoku.

Novejši slovenski godalni kvartet kaže izredno širok diapazon različnih estetskih naziranj, v okviru katerih nakazujeta Ramovš in Božič, vsak na svoj način, nove, popolnoma sodobne rešitve $\mathrm{v}$ tem glasbenem mediju, pa tudi nove probleme.

\section{SUMMARY}

The string quartet of the 20th century has not remained a medium on the fringes, for which nothing new in the way of musical expression can be devised; on the contrary, it has followed and at times even provided an essential contribution to the picture of musical striving in this century: such was the case with Hindemith, with Schönberg and with Webern, not to mention the master of quartets - Béla Bartók. In Slovene music, their contemporary Slavko Osterc found a modern solution to the question of quartet sound and form with his 2nd string quartet (1934). Several decades were to pass before his technical and stylistic solutions were surpassed, and that at a level high enough to satisfy international criteria.

The article deals with some compositionally characteristic post-war quartets, beginning with the 5th string quartet (1945) by Lucijan Marija skerjanc, which in spite of its late date is still floating in post-romantic waters, whose sources go back to Smetana, Tchaikovsky, Mahler and Ravel. The string quartet by Ivo Petrić from 1956 is the first to freshen the atmosphere to some extent with its Hindemithian "Fortspinnung" and Bartókian treatment of south Slavonic folklore. In contrast to the widely held opinion that folklore is hardly present in Slovene music - in comparison with compositions from other regions of Yugoslavia - the 3rd string quartet (1959) by Vilko Ukmar cannot conceal its folkloric elements.

${ }^{24}$ Prim. Globokar v., Jom Reagieren, Melos XXXVI/1972, 2/59-61. 
The tonally decentralized idiom oscillates between something which could be called "romantic expressionism « and standard expressionism. The Two compositions for string quartet (1968) by Vladimir Lovec are treated as a belated example of neo-classicism. Not until 1969 does the string quartet catch up with modern European and to some extent also with avant-garde sound solutions in this medium (other types of composition had done so long ago). In this respect Quatuor (1969) by Ivo Petrić and Triptychon (1969) by Primož Ramovš are especially important. While Petrićs literary Italian adverbs represent further emotional preconditioning of the performance, Ramovš's changes of density, colour and dynamics have become the exclusive components of the work's »contents«. Sound has here become an end in itself, self-sufficient, with no extra-tonal imputations. In contrast to Petrić's quartet Ramovš's is extra-musically, explicitly non-programmatic and thus is more daring and more avant-garde. Pop-art III for string quartet (1971) by Darijan Božič goes even further because of the increased exploitation of the performers' creative potential. So the contemporary slovene string quartet reveals a wide diapason of different aesthetic attitudes within which Ramovš and Božič, each in his own way, are pointing the way towards new solutions in this musical medium but also towards new problems. 